 \\ В Институте им. А.В. Вклифосовского [1960-1986 гт.]. Demijov V.P. Transplante experimental de órganos vitales. Madrid: Editorial Atlante, 1967
}

\author{
С.П. Глянцев ${ }^{\varpi 1,2}$, Ю.Г. Шатунова ${ }^{3}$, А. Вернер 4 \\ 1 ФГБУ «НМИЦ ССХ им. А.Н. Бакулева» Минздрава России, \\ 121552, Россия, Москва, Рублевское ш., д. 135; \\ 2 ФГБНУ «ННИИ ОЗ им. Н.А. Семашко», \\ 105064, Москва, ул. Воронцово поле, д. 12, стр. 1; \\ ${ }^{3}$ ФГАОУ ВО «Первый МГМУ им. И.М. Сеченова» Минздрава России, \\ 119991, Москва, ул. Трубецкая, д. 8, стр. 2; \\ ${ }^{4}$ Клиника кардиоторакальной хирургии ХЕЛИОС-клиники Крефельда, \\ 47805, Германия, Крефельд, Лутерплатц, д. 40
}

Автор, ответственный за переписку: Сергей Павлович Глянцев, проф., д-р мед. наук, заведующий отделом истории сердечно-сосудистой хирургии НМИЦ ССХ им. А.Н. Бакулева, заведующий сектором истории медицины и фрактографии отдела истории медицины ННИИ ОЗ им. Н.А. Семашко, spglyantsev@ mail.ru

\section{Аннотация}

В статъе впервые введено в научный оборот и проанализировано переведенное авторами на русский язык предисловие В.П. Демихова кего книге «Пересадкажизненно-важных органов в эксперименте», вышедшей в 1967 г. на испанском языке под названием "Transplante ехреrimental de órganos vitales». Судя по упомянутыл в тексте бактам, В.П. Демихов написал его в 1966 г., отразив свои взгляды на современное ему состояние и перспективь гомопластической пересадки тканей и органов. Как и в предъдущих работах, в частности, в предисловии к немеикому изданию книги, вышедией в Берлине в 1963 г., В.П. Демихов обосновал положение о том, ито основным условием успешной гомопластической пересадки органов является восстановление в них кровообращения. По его мнению, успех приживления зависит, прежде всего, от идеально выполненного сосудистого шва и немедленного включения пересаженного донорского органа в кровоток организма хозяина, а также от стерильности проведенного вмешательства. Обсудив применение бармакологической иммуносупрессии как метода преодоления биологической несовместилости гомологичных органов при их пересадках, В.П. Демихов указал на токсичность используемых для этой цели препаратов, испытанных им в условиях эксперимента, а также на свои опыты, свидетельствуюшие о возможности преодоления несовместимости другими методами (подбор донора и рециичента по группам крови, смешивание крови донора и реципиента путем парабиоза и др.). В этом тексте В.П. Демихов вновъ упомянул о разработанной им схеме двухэтапной пересадки дополнительного сердиа в качестве резервного органа для поддержания бункиии декомпенсированного сердиа больного и назвал основные этапы операции: подсадка на бедренные сосуды (1-й этап) и трансплантация в грудную клетку (2-й этап). Как и в предисловии к немеикому изданию книги, В.П. Демихов подробно рассказал о разработанной ил в 1963 г. модели «живой физиологической системъ» с изелъю создания банка реанимированных органов, которые сохраняли бы свою жизнеспособность до пересадки в другой организм. Также бъли изложены проекты о выращивании органов у новорожденных диэнцеббалов для омоложения стариков.

Ключевые слова: история медицины, трансплантология, В.П. Демихов, V.P. Demijov, Transplante experimental de órganos vitales, 1967

КонФликт интеРесов Авторы заявляют об отсутствии конфликта интересов

Финансирование Исследование проводилось без спонсорской поддержки

Для цитирования: Глянцев С.П., Шатунова Ю.Г., Вернер А. Феномен Демихова. В Институте им. Склифосовского (1960-1986 гг.). Demijov V.P. Transplante experimental de órganos vitales. Madrid: Editorial Atlante, 1967. Трансплантология. 2021;13(1):74-92. https://doi.org/10.23873/2074-0506-2021-13-1-74-92 


\title{
PHENOMENON OF DEMIKHOU. In the Sklifosovsky Institute [1960-1986]. Demijov V.P. Transplante experimental de órganos vitales. Madrid: Editorial Atlante, 1967
}

\author{
S.P. Glyantsev $\bowtie 1,2$, Yu.G. Shatunova ${ }^{3}$, A. Werner ${ }^{4}$ \\ ${ }^{1}$ A.N. Bakoulev National Medical Research Center for Cardiovascular Surgery, \\ 135 Roublyevskoe Hwy., Moscow 121552 Russia; \\ ${ }^{2}$ N.A. Semashko National Research Institute of Public Health, \\ 12 Bldg. 1 Vorontsovo Pole St., Moscow 105064 Russia; \\ ${ }^{3}$ I.M. Sechenov First Moscow State Medical University (Sechenov University), \\ 8 Bldg. 2 Trubetskaya St., Moscow 119991 Russia; \\ ${ }^{4}$ Cardiothoracic Surgery Clinic, HELIOS Hospital Krefeld, \\ 40 Lutherplatz, Krefeld 47805 Germany
}

${ }^{\square}$ Corresponding author: Sergey P. Glyantsev, Prof., Dr. Sci. (Med.), Head of the Department of the History of Cardiovascular Surgery at A.N. Bakoulev National Medical Research Center for Cardiovascular Surgery, Head of the Medical History Unit within the Medical History Department at N.A. Semashko National Research Institute of Public Health, spglyantsev@mail.ru

\begin{abstract}
Alsstract
For the first time, the article introduces into scientific circulation and analyzes the Preface by V.P. Demikhov to his book "Transplantation of vital organs in experiment", published in 1967 in Spanish under the title "Transplante experimental de órganos vitales". Judging by the facts mentioned in the text, V.P. Demikhov wrote it in 1966, reflecting his views on the current state and prospects of homoplastic tissue and organ transplantation. As in previous publications, in particular, in the Preface to the German edition of the book published in Berlin in 1963, V.P. Demikhov substantiated the concept that the main condition for a successful transplantation of homoplastic organs was to restore the blood circulation in them. In his opinion, the success of engraftment depends, first of all, on the ideally performed vascular suture and the immediate inclusion of the transplanted donor organ into the blood circulation of the host body, as well as on the sterility of the undertaken intervention. Having discussed the use of pharmacological immunosuppression as a method of overcoming the biological incompatibility of homologous organs during their transplantation, V.P. Demikhov pointed out the toxicity of the drugs used for this purpose he tested experimentally, as well as his experiments, indicating the possibility of overcoming incompatibility by means of other methods (the selection of the donor and recipient with regard to the blood group, mixing the blood of the donor and recipient by parabiosis, etc.). In this text V.P. Demikhov again mentioned the scheme he had developed for two-stage transplantation of an additional heart as a reserve organ to maintain the function of the patient's decompensated heart and named the main stages of the operation: implantation on the femoral vessels (stage 1) and transplantation into the chest (stage 2). As in the Preface to the German edition of the book, V.P. Demikhov spoke in detail about the model of a "living physiological system" he had developed in 1963 aimed at creating a bank of reanimated organs that would retain their viability until transplanted into another body. Projects for growing the organs in anencephalic newborns for the rejuvenation of the elderly were also outlined.
\end{abstract}

Keywords: history of medicine, transplantation, V.P. Demikhov, V.P. Demijov, Transplante experimental de órganos vitales, 1967

CONFLICT OF INTERESTS Authors declare no conflict of interest

FinanCing

The study was performed without external funding

For citation: Glyantsev SP, Shatunova YuG, Werner A. Phenomenon of Demikhov. In the Sklifosovsky Institute (1960-1986). Demijov V.P. Transplante experimental de órganos vitales. Madrid: Editorial Atlante, 1967. Transplantologiya. The Russian Journal of Transplantation. 2021;13(1):74-92. (In Russ.). https://doi.org/10.23873/2074-0506-2021-13-1-74-92 


\section{HISTORY OF MEDIGIME}

\section{Введение}

После того, как в 1960 г. книга В.П. Демихова «Пересадка жизненно-важных органов в эксперименте» вышла в Москве на русском языке [1], в 1962 г. она была переведена на английский язык и издана в Нью-Йорке [2], а в 1963 г. вышла в свет в Берлине на немецком языке [3]. В октябре 1967 г. книга под названием "Transplante experimental de órganos vitales" стала издаваться в Мадриде на испанском языке (рис. 1, 2) [4].

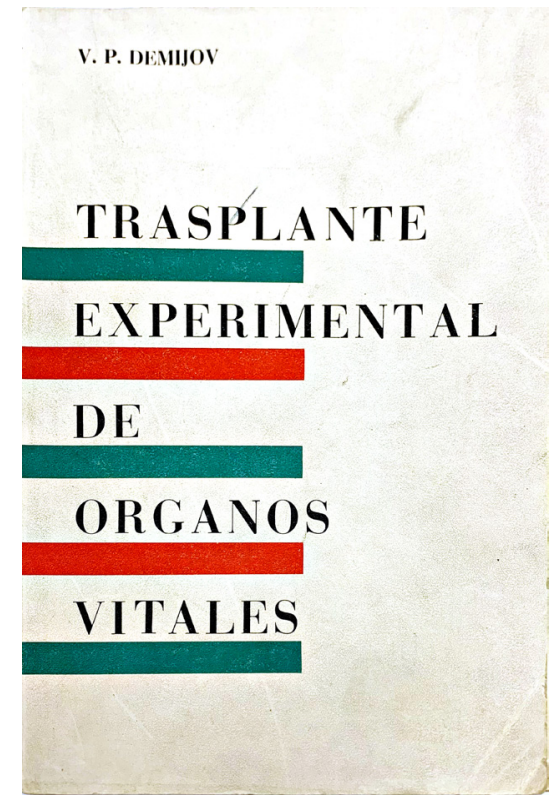

Рис. 1. Обложка книги В.П. Демихова "Transplante experimental de órganos vitales" (Madrid, 1967) [Музей НМИЦ ССХ им. А.Н. Бакулева МЗ РФ]

Fig. 1. The cover of the book by V.P. Demikhov "Transplante experimental de órganos vitales" (Madrid, 1967) [Museum of A.N. Bakulev National Medical Research Center of Cardiovascular Surgery]

В этой связи подчеркнем три фракта:

1. С этого времени книга В.П. Демихова стала единственной из известных нам хирургических монографий, изданной на четырех ведущих европейских языках - русском, английском, немецком и испанском.

2. В настоящее время испанский язык занимает 2-е место по количеству его носителей среди языков мира (на нем говорят 460000000 человек); английский язык по распространенности - 3-й в мире (379 миллионов), но среди официальных языков $\mathrm{OOH}$ - первый (за ним идут французский, русский, китайский, арабский и испанский);

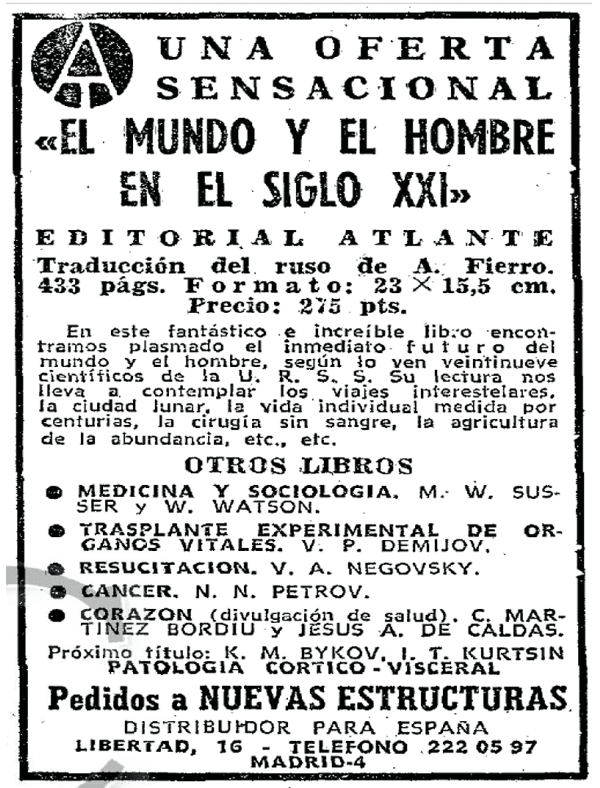

Рис. 2. Фрагмент ежедневной газеты «АВС» за 19 октября 1967 г. (Мадрид, четверг, утренний выпуск) [копия; из архива A. Werner]

Fig. 2. Fragment of the $A B C$ daily newspaper of October 19, 1967. (Madrid, Thursday, morning edition) [copy from A. Werner's archives]

русский язык по числу носителей занимает 8-е место в мире (154 миллиона), немецкий - 17-е [5].

3. Тем не менее, в современной научной литературе превалирует английский язык: на нем выходит 64\% публикаций, что в определенном смысле становится барьером для распространения научных знаний, особенно среди испаноязычного сообщества [6].

Последний фракт доказывают библиометрические исследования: несмотря на наличие работ, авторы которых цитировали книгу В.П. Демихова на испанском языке, их пристатейные списки литературы, как правило, включали название книги и транскрипцию фамилии автора на английском языке и, таким образом, попадали в англоязычную, а не испаноязычную статистику цитирований. Поэтому сделать вывод о цитируемости испаноязычного перевода книги нам не представилось возможным [7].

Отметим еще одну деталь: перевод книги В.П. Демихова на испанский язык был сделан с ее английского издания. Переводчиком англоязычного текста стал доктор Fernando Cardenal. Напомним, однако, что у английской версии книги, вышедшей через два года после русского оригинала, предисловия автора не было. Книгу предварял лишь короткий текст «От издатель- 


\section{HISTORY OF MEDIGINE}

ства». Первое авторское предисловие, написанное В.П. Демиховым, увидело свет в 1963 г. в немецком переводе книги и было обсуждено нами ранее [8]. Перевод авторского предисловия с русского на испанский сделал известный переводчик советской научной и публицистической литературы A. Fierro. K сожалению, его русского оригинала у нас нет. С испанского на русский текст перевела Ю.Г. Шатунова. Красные строки в тексте (абзацы) приведены по испанскому оригиналу, который, как и в книге, дан курсивом (рис. 3). Мы добавили лишь короткие заголовки, структурирующие текст, и необходимые комментарии.

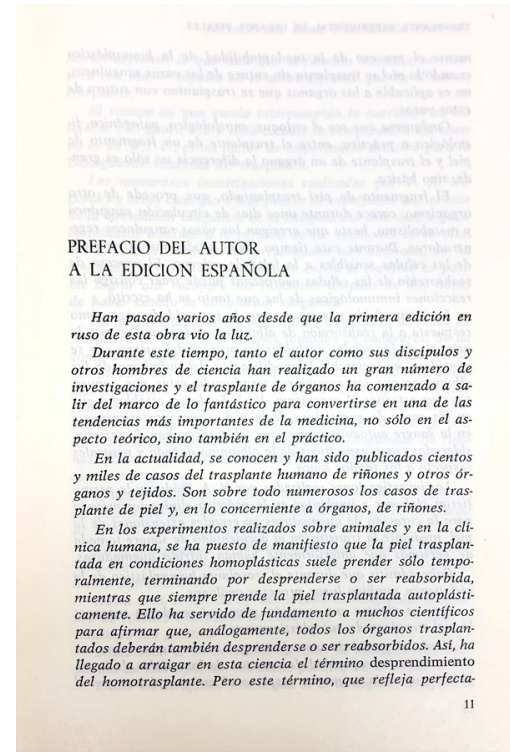

Рис. 3. Первая страница предисловия к книге В.П. Демихова "Transplante experimental de órganos vitales" (Madrid, 1967) [Музей НМИЦ CСX им. А.Н. Бакулева МЗ РФ]

Fig. 3. The first page of the Preface to the book by V.P. Demikhov "Transplante experimental de órganos vitales" (Madrid, 1967) [Museum of A.N. Bakulev National

Medical Research Center of Cardiovascular Surgery]

С момента выхода книги в Германии (предисловие к немецкому изданию) до ее перевода на испанский язык прошло 4 года, поэтому мы сочли важным познакомить читателя с концепциями и рассуждениями В.П. Демихова, сложившимися у него к 1966 г., когда, по нашему мнению, он и написал предисловие к испаноязычному изданию своей книги (рис. 4).

За эти годы в области трансплантологии произошли события, изменившие взгляды хирургов и иммунологов на проблему гомологичной пересадки органов и возможности контролиро-

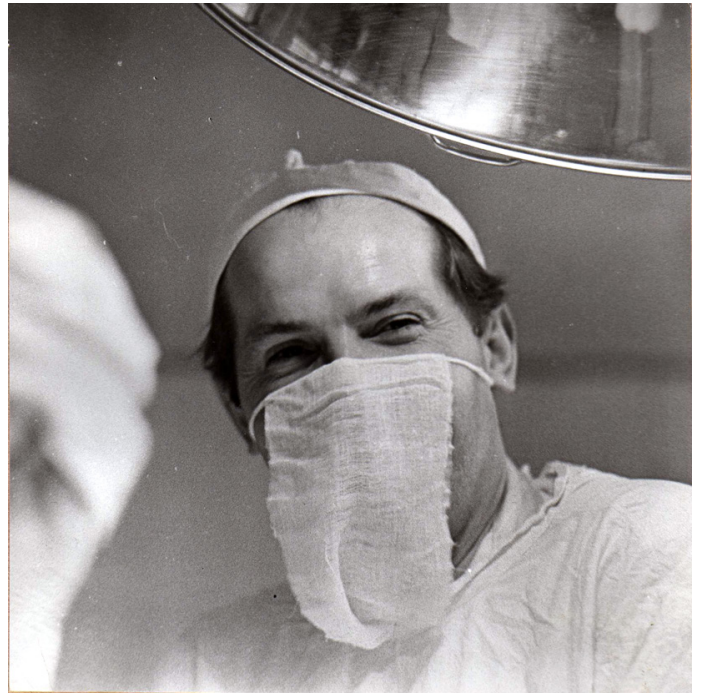

Рис. 4. В.П. Демихов. 1960-е гг. [Музей НМИЦ ССХ им. А.Н. Бакулева МЗ РФ]

Fig. 4. V.P. Demikhov. 1960s. [Museum of A.N. Bakulev National Medical Research Center of Cardiovascular Surgery]

вать их приживление. В частности, была изучена роль лимфоцитов крови в процессе отторжения организмом чужеродных тканей. Было показано, что ядросодержащие клетки гомологичных органов содержат белки, играющие роль антигенов, которые связываются лимфоцитами крови реципиента. Эти клетки инфильтрируют ткани в месте соединения гомооргана с организмом реципиента, в результате чего происходит отторжение трансплантата. Кроме того, была доказана важность раннего контакта эмбриона животных и человека с белковыми антигенами для их распознавания по принципу «свой - чужой». За эти исследования в 1960 г. англичанин P.B. Medawar (1915-1987) из Лондона и австралиец F.M. Burnet (1899-1985) из Мельбурна были удостоены Нобелевской премии [9]. После открытия феномена иммунологической толерантности появилась новая теория трансплантационного иммунитета, согласно которой способность к распознаванию своих и чужих белков не наследуется организмом, а развивается в период внутриутробной жизни плода.

Благодаря новой парадигме при пересадке органов стали применять фрармакологические препараты (гормоны, 6-меркаптопурин, антилимфроцитарную сыворотку и др.), блокирующие иммунный ответ, в результате чего были достигнуты существенные успехи, в частности, в области пересадки почек, эксплантированных не только у родственных доноров, но и у трупов. В 
1965 г. первую успешную родственную пересадку почки в СССР провел Б.В. Петровский.

Анализ переведенного нами текста показал, что со всеми этими достижениями В.П. Демихов был знаком, однако не со всеми согласен. Во-первых, потому, что новая теория иммунитета к 1966 г. еще не стала общепризнанной, по крайней мере, в CCCP [10], а во-вторых, результаты его собственных наблюдений не укладывались в ее рамки.

Demijov V.P.

Transplante experimental de órganos vitales. Madrid: Editorial Atlante, 1967

\section{ПРЕДИСЛОВИЕ АВТОРА \\ К ИСПАНСКОМУ ИЗДАНИЮ}

"Прошло несколъко лет с момента въхода в свет первого издания этого произведения на русском языке (1960 г. - Авт.).

За это время автор, его ученики и другие ученъе провели много исследований, а трансплантация органов стала выходить за рамки бантастики, чтобы стать одним из важнейших направлений в медицине. Не только в теоретическом аспекте, но и в практическом.

В настоящее время известны и опубликованы сотни и тысячи случаев трансплантации почек и других органов и тканей человеку. Особенно много случаев трансплантации кожи, а в отношении органов - почек».

\section{О трансплантации кожи}

"В экспериментах, проведенных на животных и у человека, бъло показано, что кожа, пересаженная в гомопластических условиях, имеет тенденциию приживаться временно, в конечном итоге отслаиваясь или реабсорбируясь, в то время как аутопластически пересаженная кожа приживается всегда. Это позволило многим ученым утверждать, что гомопластически пересаженные органы также должны отслоитъся (при упоминании далее в тексте об «отслаивании» органов мы будем использовать термин «отторжение». - Авт.) или реабсорбироваться. Так в трансплантологии появился термин "гомотрансплантационная отслойка» (исп. desprencimien to del homotransplante. - Aвт.). Но этот термин, который отражает [4, с. 11] ${ }^{1}$ прочесс гомопластической отслойки кожи, пересаженной без соединения кровеносных сосудов, не применим $к$ органам, пересаженным на сосудистых анастомозах.

Независимо от подхода: морбологического, патологического, физиологчческого или клиниче- ского, между пересадкой брагмента кожи и пересадкой органа разница не только велика, но и приниципиальна.

Пересаживаемый фбрагмент кожи, который берется у другого организма, не илеет кровообращения, поэтому обмен веществ в нем в течение нескольких дней, пока не регенерируют кровеносные сосуды, отсутствует. В течение этого времени происходит некроз чувствительных $к$ кислороду клеток. Проиесс их реабсорбиии влечет за собой иммунологические реакиии, о которьх много писали.

Имлунология учит нас, что имлунитет возникает как ответ на реабсорбицю чужеродных альбуминов. В некротизированных клетках, пересаженных из другого организма, происходит изменение химического состава альбуминов, из которых они состоят, и которые в конечном итоге неизбежно станут чужими для организма хозяина. H.А. Федоров ${ }^{2}$ установил, что при ожогах кожи в крови пострадавшего можно обнаружить аутоантитела, которье являются специябическими для алъбумина поврежденной кожи и нейтралънъми по отношению $к$ здоровым тканям.

Исследования, проведенные Н.А. Федоровым, позволили ему разработать и внедрить в клиническую практику метод лечения обожженных с обиирными ожогами переливанием крови, взятой от людей, ранее перенесших ожоги.

По общему мнению, аналогичные процессы происходят и при пересадке гомопластической кожи.

Но возникает вопрос, почему же тогда адаптируется и приживает аутопластически пересаженная кожа?»

\section{О значении восстановления кровообращения} в пересаженных тканях (кожа, кровь) и органах (почки)

"С бозиологической точки зрения можно предположить, что реакиия тканей ожоговой ранъ при аутотрансплантации менъше по сравнению [4, с. 12] с гомотрансплантацией, что приводит $к$ более бъстрому восстановлению кровообращения в пересаженной коже при ее аутотрансплантаиии, чем при гомотрансплантации.

Время, в течение которого кровоснабжение тканей и органов прерывается, особенно при телпературе тела $+37,5^{\circ} \mathrm{C}$, является решаюшим бактором для последуюшей жизнеспособности трансплантата.

Многочисленные исследования В.А. Неговского ${ }^{3}$ и других ученъх показали, что прекращение кровообращения в головном мозге на 10-15 минут при-

${ }^{1}$ Первая цифрра в квадратных скобках означает порядковый номер источника, вторая - страницу в нем.

${ }^{2}$ Федоров Н.А. (1904-1983), советский патофизиолог, действительный член АМН СССР (1963), академик-секретарь ОМБН АМН СССР; работал главным редактором журнала «Патологическая физиология и экспериментальная терапия».

${ }^{3}$ Неговский В.А. (1909 - 2003), советский патофизиолог; дважды лауреат Государственной премии СССР, действительный член АMH СССР (1975); основоположник реаниматологии как врачебной специальности и научной дисциплины, создал и возглавил первый в мире Институт общей реаниматологии (ныне НИИ общей реаниматологии им. В.А. Неговского ФНКЦ реаниматологии и реабилитологии). 
водит к утрате его фбункици. С другой стороны, в эксперилентах, проведенных на животных, было показано: если мозг предварительно охладить, то можно заставить его восстановить свои фбункиии даже через два часа после остановки кровообращения.

В настоящее время известно несколько сотен случаев трансплантаиии больному человеку почек, взятых от трупов. Бъло показано: если почки пересаживают по прочествии более 2 часов с молента прекращения в них кровообращения, то они либо не восстанавливают свою бункциию, либо подвергаются дегенеративным изменениям. Чтобы уменъшить опасность этих изменений, после эксплантации почки охлаждают погружением их в охлаждающие растворь.

Оценка бактора времени, по-видимому, съграла немаловажную роль в успехах, достигнутых при трансплантации трупных почек.

В статистическом сборнике, опубликованном в нъю-йоркском журнале "Трансплантаиия» в 1965 г., приводятся весъма любопьтные данные.

До 1963 г. бъло проведено 45 трансплантаиий почек человеку, взятых из трупов, и только в одном случае результат был положительным.

С 1963 г. по 15 марта 1965 г. выполнено 82 трансплантации данного типа, и в 43 случаях был достигнут положительный результат.

Все хирурги знают: если наложить жгут [4, с. 13] на поврежденную конечность более, чем на два часа, то такую конечность обычно приходится ампутировать.

С әругой стороны, аутопластически пересаженный брагмент кожи останется без кровоснабжения до тех пор, пока не образуются новые сосудъ, и этот период длится не 2 часа, а в 30-40 раз дольие. Этот период, по-видимому, еще продолжительнее, когда мы имеем дело с гомопластической кожей.

С фозиологической точки зрения, это различие можно объяснить следуюшими причинами:

1. Различные ткани и органы (мозг, печенъ, мъьшиъь, кровъ, кожа, хрящ, роговича и др.) проявляют разную чувствительность $к$ временной остановке кровообращения;

2. Верхний слой кожи менее чувствителен $\kappa$ прекращению кровообращения и в течение длительного периода времени сохраняет свою жизнедеятельность за счет дифббузии межклеточной жидкости. С әругой стороны, хряш и роговииа не нуждаются в кровообрашении, поскольку их жизнедеятельность обеспечивается лилфой.

3. Большое значение имеет используемая техника трансплантации. Давно известно, что при трансплантации органов и крупных фбрагментов тканей их ассимиляичи или адаптации не проис- ходит даже в случае аутотрансплантаици. Уже в XIX веке русский онколог Новинский смог проверить, а в нашем веке его ученики подтвердили, что если опухоль, разделенную на относительно больиие брагменты, пересадить, то она не приживет, но если ее разделить до частии, которье проходят через инъекциионую иглу, то пересаженные клетки будут поддерживать свою жизнедеятельность и развиваться в организме хозяина. Крочечные кусочки аутопластических мыши также не приживают. Но если этот брагмент разрушить еще более, то рост мыцечных клеток и регенерация мышечной ткани становится возможной даже при гомотрансплантаиии (эксперименты А.Н. Студитского и его учеников) [4, с. 14].

При попытке трансплантации человеку фрагмента кожи, взятого на всю толшину, опасения возникают даже при использовании аутопластики. Поэтому для пересадки используют только тонкий поверхностный слой эпидермиса (расщепленный кожный лоскут. - Авт.), который менее чувствителен $\kappa$ нарушению кровообращения, и в которьй окружающая интерстициальная питательная жидкость может проникать за счет лимбатической ииркуляиии.

Гистологические исследования показали, что при гомопластической пересадке кожи часто отслаивается не весь трансплантат, а лишь внешняя его часть, внутренняя же часть сохраняет свои элементы.

4. У человека и у различных животных фбизиологические и анатомические особенности не идентичны. У мелких животных (мыиии, крысы) толшина кожи по сравнению с кожей человека мала, поэтому условия дибббузного питания трансплантата могут быть такими же, как и для тонкого верхнего слоя трансплантата человеческой кожи.

С биологической точки зрения разнииа между разными видами животных и человека очень вели$\kappa a$.

Разные животные и человек по-разному реагируют на переливание крови, трансплантацию кожи, почек и т.n.

У собак переливание крови может быть выполнено независимо от групповой ее принадлежности и без негативных последствий. Мъ перелили 500,0 миллилитров человеческой крови собаке. Через 30 минут началась гематурия, сопровождавиаяся частыл мочеиспусканием, но собака выжила, а ко вторым суткам полностъю выздоровела.

С другой стороны, переливание человеческой крови от одного человека другому без учета ее группы может привести к летальному исходу. И наоборот: если кровь переливают с учетом совместимости ее групп [4, с. 15], то новая кровь выполняет те же бууниии, что и собственная.

${ }^{4}$ Новинский M.А. (1841-1914), ветеринарный врач, основоположник отечественной экспериментальной онкологии; впервые в мире осуществил трансплантацию злокачественных новообразований в эксперименте на животных; в диссертации на тему «К вопросу о прививании злокачественных новообразований» (1877) дал обзор попыток трансплантации опухолей, описал методику собственных опытов, их результаты и привел данные гистологических исследований пересаженных и привившихся опухолей. 
У крыс гомопластически пересаженная кожа приживает намного лучше, чем у кроликов.

В этих случаях (по свидетельству многих авторов) гомопластически пересаженная кожа

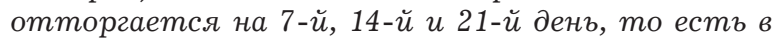
дни, которые характеризуют имлунный кризис.

У человека приживление гомопластической кожи иногда продолжается в течение нескольких меслиев.

Почки, гомопластически пересаженные собакам, выполняют свои функиии в течение двух-трех недель и редко - до 2 месяиев. При таком же типе трансплантата у человека почки продолжают выполнять свои жизненно-важные фбункции в течение многих лет.

Все это говорит нам о том, что проблема совместимости тканей и органов при трансплантаичии их человеку должна быть изучена на человеке. Если бъ переливание крови изучалось только на животных, мы бы никогда не узнали, как переливать кровъ для спасения людей.

Отсутствие опасности при трансплантаици человеческих тканей и органов, когда приняты все необходимъе меры предосторожности и доступны все технические и послеоперационные возможности, бъло продемонстрировано сотнями и тысячами успешных операций, которые были выполнены с последующим мониторингом положительного результата на протяжении многих лет».

Речь, очевидно, идет о «сотнях и тысячах успешных операций» пересадки аутокожи и переливания крови, потому что кроме нескольких десятков пересадок почек (1933) и нескольких попыток пересадить легкие, печень и поджелудочную железу (1963-1966) ко времени написания В.П. Демиховым этого текста других органов человеку не пересаживали. Интересно замечание В.П. Демихова об иммунном ответе на белки некротизированной кожи (образование ожоговых антител). Такие исследования проводились, в частности, в открытом в 1960 г. ожоговом отделении Института хирургии им. А.В. Вишневского АMH CCCP, получившем в 1967 г. статус Всесоюзного ожогового центра.

О пересадке роговицы и хряща

"Пересадка роговицы, взятой от mpyna nо методике, разработанной В.П. Филатовыл, вернула зрение тысячам людей. Трупная роговица не отслаивается и не растворяется в отличие от гомопластически пересаженной кожи, хотя в некоторых случаях она теряет прозрачность. В последнее время это, как правило, рассматривается как следствие присоединения инфекции при выполнении операции и не относится $\kappa$ реакииям иммунитета. Известно также, что роговица может утратить прозрачность [4, с. 16] даже в отсутствие травмы или инфбекичи транспланmama.

Также хорошо приживает хрящ, пересаженныци от трупа к живому существу. Количество операицй этого типа исчисляется тысячами.

Специалисть-имлунологи объясняют этот феномен полным отсутствием антигенов или их присутствием в небольшом количестве в роговице, хрящах и других легко адаптируемых тканях.

С фбизиологической точки зрения гомопластическое приживление роговищы и хряща объясняется тем, что эти ткани идеально приспособленъ для существования с пониженным метаболизмом за счет лимбатического кровообращения, в то время как кровообращение не только не приносит им пользу, а скорее контрпродуктивно, так как может привести к потере прозрачности роговииъ. Именно поэтому эти ткани могут храниться в течение длительного времени после их извлечения из трупа до помешения в организм реципиента. Попав в него, лилбатическая ијиркуляиия этих трансплантатов восстанавливается во много раз бъстрее, чем ииркуляиия крови в брагменте кожи».

\section{О пересадке костей и суставов}

"Пересадка человеку костей и суставов, взятьх от трупа, проходит успешно. В Советском Союзе в течение нескольких лет было проведено несколько тысяч таких операций с контролируельми положительныли результатами.

В 1913 г. всемирно известный немеикий хирург Lехет безуспешно пьтался пересадить сустав человеку. Неудачу объяснили несовместимостью тканей. Другие хирурги согласились с таким объяснением, в результате чего во время двух последних мировых войн пересадки костей и суставов не проводилисъ.

Сейчас известно, что для успешной трансплантаиии костей и суставов, взятых от трупов, проияедуры консервации и методы, которые будут использоваться в операции, должны быть более совершенными.

Успешное приживление такого объемного органа [4, с. 17], как коленный сустав и тазобедреннъй полусустав с фбизологической точки зрения можно объяснить тем, что кости и суставы не чувствительны $к$ нарушению кровообращения $и$ способны поддерживать жизнедеятельность за счет лимбообращения».

\section{Еще раз о значении кровообращения при пересадке органов}

"Когда при трансплантачии органов кровообращение восстанавливается через анастомозированные сосуды, то длительного перерыва в питании тканей нет, они сохраняют свою жизнеспособность, не происходит их аутолиза $и$, как следствие, в них не создаются условия для возникновения имлунных реакиий с иелью отторжения. 
Многочисленные әксперименты по пересадке органов, которые мы проводили в течение многих лет, показали, что их жизнедеятельность в новом организме сохраняется до тех пор, пока продолжается кровообращение. Как только оно прерывается, развивается некроз с последуюшим отслаиванием или рассасъванием кожи, а в других органах - обычные дегенеративные патологические прочессъ.

Очень сложно определить как время, в течение которого кровообращение остается прерванным, так и момент его восстановления, когда брагмент кожи пересаживается объчным методом.

Через тонкий слой пересаженной кожи кровеносные сосуды открытой раны реципиента излучают тепло в окружающее пространство, в результате пересаженная кожа легко нагревается. Следовательно, этот критерий, с помошью которого можно определить жизнедеятельность кожного трансплантата (температура пересаженного лоскута кожи, измеренная контактным способом или на расстоянии. - Авт.), не может бъть использован.

Oтсутствует и окончательный критерий гистологический анализ трансплантата, так как он либо отслаивается в виде сухой корки или в аморбном состоянии, либо бесследно растворяется, не оставля ничего для гистологического исследования. При этом проиессы отслоения и растворения обнаруживаются наблюдателем лишь тогда, когда [4, с. 18] с момента остановки кровообращения в трансплантате прошло несколько дней. Таким образом, мертвый трансплантат в эти дни остается при телпературе тела (от $+37^{\circ} \mathrm{C}$ до $\left.+38^{\circ} \mathrm{C}\right)$ и в контакте с окружаюшей микробной блорой.

В этих условиях через два-три дня после смерти человеческий труп начинает разлагаться, $и$ даже кожа, которая не бъла пересажена, мащерируется; то есть она изменяется сама по себе, без участия гуморальных или агглютиногенных антител.

В обычных условиях у трупа сложно наблюдать мацерацию или отслойку верхнего слоя кожи, так как либо родственники хоронят его, либо, если труп находится в морге, его хранят в холодном помещении.

Во время войны в жаркие летние дни мне, военному врачу-патологоанатому (в 1941-1945 гг. В.П. Демихов служил в армейской патологоанатомической лаборатории. - Авт.), доводилосъ, $к$ сожалению, довольно часто наблюдать эти явления. У мертвых животных маиераиия верхнего слоя (за исключением области молочных желез у самок) практически не возникает из-за шерсти, покрывающей кожу.
Отслойка верхнего слоя кожи также часто наблюдается у живых людей, особенно на открьтых местах, из-за длительного воздействия солнечных лучей. Если это воздействие осуществляется бъстро, то возникает солнечный ожог, которъй приводит к гиперемии кожи и, через три-четыре дня, ее отшелушиванию; то есть отслойке верхнего слоя без участия бактериальной фблорь.

Отслоение кожи вследствие этих трех различных явлений (отслойка свободного пересаженного кожного лоскута, отслойка мацерированной кожи у трупа и отслойка кожи после солнечного ожога. Авт.) възвано одной и той же причиной: некрозом ткани из-за прекращения кровообращения.

Отслоение трансплантата, мацерация или отшелушивание наблюдаются только при трансплантации поверхностных слоев кожи или с захватом ее срединного слоя. Но при трансплантации внутренних органов их отслойки не происходит, хотя этот термин [4, с. 19] чисто механически относят, например, к конечностям при их гомологичной пересадке (гангрена влажная или сухая). Механическое (небункицональное) применение этого термина объясняется тем, ито больиинство специалистов в области имлунологии часто сталкиваются при пересадке кожи со случаями отслойки кожи, но они не знают, что происходит с внутренними органами при их трансплантации. У них также нет возможности наблюдать гистологическую структуру кожного гомотрансплантата, так как он либо отслаивается, либо растворяется, либо высъхает.

В монограбби по трансплантаиии кожи, изданной в 1966 г., С.Ш. Хундадзе описал результатъ гистологического исследования кожных трансплантатов, проведенного с использованием биопсии.

Автор сделал вывод, что "в течение первых 48 часов после гомотрансплантаиии наблюдается пикноз в ядрах эпидермальных клеток гомотрансплантата и деполимеризаиия ицитоплазматических ядер нуклеопротеидов. Некроз трансплантата заканчивается через пять дней после операции, а через 15 или 20 дней форагмент кожи полностью отделяется от тканей тела реиипиента».

Таким образом, отслаивание гомопластически пересаженной кожи происходит через много дней и недель после их гибели из-за отсутствия реваскуляризации.

С другой стороны, когда проводят пересадку кожи и даже конечностей у мелких животных, например, крыс с использованием временного парабиоза (эксперименты Justin Schvind ${ }^{6}$, А.Г. Лапчинского ${ }^{7}$ и др.), то по истечении 9 дней происходит адаптация гомотрансплантата к новым условиям существования, которая сохра-

${ }^{5}$ Хундадзе С.Ш. К вопросу свободной пластики кожи. - Тбилиси: Сабчота Сакартвело, 1966.

${ }^{6}$ Правильно - Schwind, «американский Демихов»; с 1936 г. занимался проблемой гомопластической пересадки органов; в 1962 г. опубликовал статью о гомопластике конечностей в условиях парабиоза [11].

7 Лапчинский А.Г. (1908-1982), советский хирург-трансплантолог; с 1960 г. руководил лабораторией пересадки органов ЦИТО им. Н.Н. Приорова; в 1970 г. защитил докторскую диссертацию на тему «Аутотрансплантация и гомотрансплантация конечности в эксперименте». 
няется до естественной смерти животного. В условиях парабиоза достигается хорошее сращение кожи двух животных. На это обстоятельство первым обратил внимание известный немеикий хирург Sauerbruch ${ }^{8}$. Впоследствии это бъло подтверждено большим количеством исследователей. Автор этих строк также добился идеального срашения кожи двух крыс в условиях парабиоза, не прибегая к какой-либо спеицбической терапии [4, c. 20].

Специалисть-иммунологи придерживаются мнения, что сращение кожи у двух организмов в условиях парабиоза происходит в результате адаптации одного организма $к$ другому в результате беномена иммунологического паралича. $C$ бозиологической точки зрения это (с наибольшей вероятностью) можно объяснить оптимальными условиями кровообращения между соединяемыми тканями.

Автору удалосъ (в эксперименте. - Авт.) разработать процедуру трансплантации грудины и покрывающей ее кожи с практически мгновенным восстановлением кровообращения путем сшивания питаюших пересаживаемый фрагмент сосудов. Во всех случаях, когда инфекиия $u$ /или тромбоз не возникали, сращение гомопластически пересаженной кожи наблюдалось путем первичного натяжения. Когда в трансплантате поддерживалось кровообращение, отслоения или растворения его не происходило.

Пересаженная кожа головы или одной из конечностей также идеально приживалась путем первичного натяжения, если кровообращение в пересаживаемом брагменте восстанавливалось немедленно. В этих случаях смерть трансплантата без отслоения или рассасъьвания бъиа вызвана прекрашением кровообращения».

\section{О значении нарушений кровообращения в пересаженном органе}

"При трансплантации кожи или конечности прочессы, которые следуют за прекращением кровообращения, относятся $\kappa$ типу гангрены, тогда как при трансплантаиии внутренних органов они происходт по типу дегенеративных изменений, которые наблюдаются в общей патологии человека (некробиоз).

Вокруг органа, который начинает умиратъ, появляется местная воспалительная реакиця в виде отека и клеточной инбильтрации с последуюшим образованием биброзной капсулы.

Кровообращение обычно прерывается в результате тромбоза в месте одного из артериальных сосудистых швов или образования плотнъхх ббиброзных тяжей [4, с. 21], сдавливаюших венъ, по которыл кровъ возвращается из трансплантата.
Тромбоз в области сосудистых швов возникает только в тех участках, где повреждена интима, или же она выходит за пределы наружной оболочки кровеносных сосудов.

Когда сосудистый шов наложен безупречно, а поврежденная интима не выходит за предель стенки артерии, ее тромбоз не возникает.

Известно, что инбицированная рана гранулирует длительно, с образованием соединительной ткани.

Подобная ткань также образуется вокруг крупных кровеносных сосудов, питаюших трансплантат. Давление крови в артерии объчно высокое, поэтому количество крови, поступаюшей $к$ трансплантату, практически не изменяется. Но давление крови в вене низкое, поэтому отток крови из трансплантата из-за медленного сдавления вень начинает постепенно уменьшаться. Это приводит к венозному полнокровию, отеку и последуюшей гибели пересаженного органа.

Хирургическое удаление спаек вокруг сдавленной венъ трансплантата приводит к бъстрому исчезновению отека (в течение одного-двух часов) $и$ восстановлению жизнедеятельности. Это наглядно демонстрирует тот gбакт, что отек, которьй часто наблюдается при ауто- и гомотрансплантаиии конечностей, имеет фбизиологическое, а не иммунобиологическое происхождение».

И снова, уже в который раз, В.П. Демихов постулирует две основных (по его мнению) причины неудачи трансплантации: тромбоз питающей трансплантат артерии и сдавление рубцами вены с нарушением оттока крови от трансплантата. Об иммунологических причинах, в которые, впрочем, он не верил, В.П. Демихов скажет ниже.

\section{Об антителах при пересадке органов}

"Часто при иммунологических исследованиях антитела не обнаруживают, или же, если они существуют, их титр очень мал. В остальных случаях повышение титра антител и отслоение кожного трансплантата не совпадают по временu.

До сих пор, несмотря на то, ито многие ученые из многих стран в течение почти 50 лет проводили имлунологические исследования, свлзанные с трансплантаиией кожи, не был решен важный вопрос: появляюшиеся в крови антитела являются причиной гибели трансплантата или следствием его гибели? [4, с. 22]. Также неизвестно, влияют ли эти антитела на жизнедеятельность трансплантата?»

${ }^{8}$ Возможно, В.П. Демихов имел в виду: Sauerbruch R, Heyde M. Ueber Parabiose kunstlich vereinigter Warmbliiter. Munch Med Wochenschr. 1908;55:153-156. 
О роли лимфоцитов

в процессе отторжения органов

«P. Medawar, лауреат Нобелевской премии за работы по трансплантации кожи, писал в журнале "Discovery» (№ 3, 1965, Лондон), что он, как и многие другие, придерживается мнения, что во время трансплантации ициркулирующих в крови антител нет, но это не подтверждено (эта фрраза В.П. Демихова не совсем ясна: кем не подтверждено, когда? - Авт.). В настоящее время предполагаетсл, ито не свободные антитела, а те, которые свлзаны с лимбоиитали, должнъ индуциировать разрушение трансплантата. "Лимбоиить, возбужденные своим контактом с чужеродными клеткали, проникают в лимбатические сосуды и накапливаются в зональных узлах, где они делятся, а затем их потолство ииркулирует по телу и разрушает трансплантат. Некоторые из недавних экспериментов, проведенных Govans, похоже, подтверждают это объяснение, хотя, по сути, все это не более чем выдумки» (P. Medawar. - Курсив снят В.П. Демиховым).

Возможно, эта гипотеза верна в процессах, происходящих при трансплантации кожи, но она не подтверждается в экспериментах по трансплантации таких органов, как конечности, голова, сердије и т.д. Если бъ лимббоииты разрушили гомопластически пересаженнъй орган, они бы проникли в его сосудъ и ткани, но на практике этого не наблюдается».

В этом пассаже легко понять принцип доказательства В.П. Демихова, привыкшего доверять своим глазам и опираться на свой собственный опыт: если в его экспериментах этого нет, значит, этого не может быть. Но отсюда ясно и то, что В.П. Демихов был знаком со всеми новинками мировой прессы, посвященными трансплантации органов и исследованию иммунитета. И относился к этим публикациям весьма критически.

О пересадке головы собаки-донора на сосуды собаки-реципиента

«Проверитъ, нарушено ли кровообращение в пересаженной голове, легко.

По мере нарастания тромбоза в области шва артерии появляется анемия склеры и слизистой оболочки языка, а условные и безусловные ребблексъ начинают угасать.

При тромбозе в области шва вены, а еще чаще при сдавлении полой вены появляется ијианоз склеры и языка, за которыли следуют отек, экзоботальм и исчезновение ребблексов. Но если даже ребблексы угасли, а венозный отек от внешнего сдавления вен снят, то ицианоз склер и языка [4, c. 23], а также все реакиии полностью восстанавливаются. Безо всяких внешних раздражителей (рис. 5).

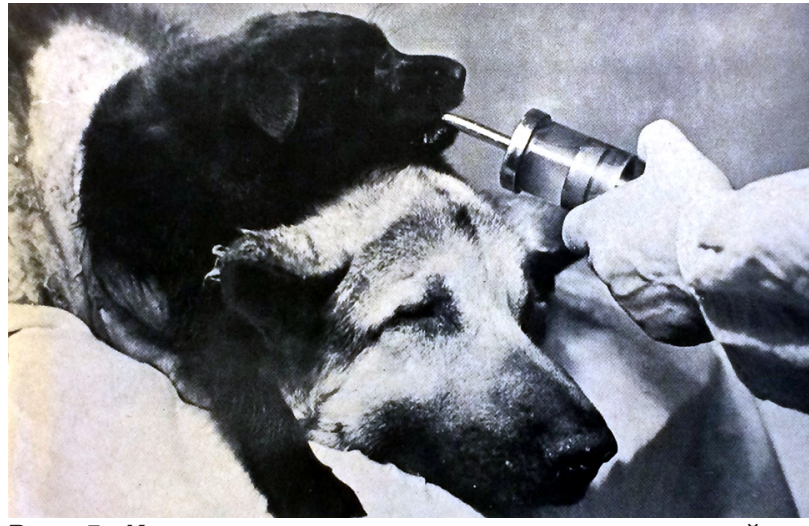

Рис. 5. Кормление головы щенка, пересаженной на сосуды шеи взрослой собаки [Bild der Wissenschaft. Januar, 1966. Р. 31; из архива A. Werner]

Fig. 5. Feeding the puppy's head transplanted onto the vessels of the neck of an adult dog [Bild der Wissenschaft. Januar, 1966. P. 31; from A. Werner's archives]

Автор этих строк не мог наблюдать отторжение пересаженной головы, поскольку, когда она умирает, ее удаляют, не дожидаясь разложения трупа, а собаку, которая действует как реципиент, сохраняют для другого әксперимента. Одной из этих больиих собак, после того, как она поправлялась от предъдущего эксперилента, одну за другой пересаживали три головы (на сосудъ шеи, печени и подвздошные сосудъ). При трансплантации головы наиболее уязвимым местом является венозный кровоток, но его характеристики отличаются от тех, что происходят в конечностях. Когда пересадку головъ выполняют на сосудъ шеи, яремная вена, по которой проходит венозный отток, легко сдавливается поворотом шеи. При пересадке головы на сосуды грудной клетки возникают плевральные осложнения (плеврит, пневмоторакс). Если для трансплантации головъ используют сосудъ почек, то вены сдавливаются органами брюшной полости и послеоперационными спайками, которые в этой полости исключительно компактнъ.

В случае с собакой по кличке Пират с двумя головами, прожившей 29 дней, заживление кожи произошло путем первичного натяжения, однако скопление фбибрина (вследствие воспаления. - Авт.) трансборлировалось в ббиброзную тканъ, которая нарушила отток венозной крови от головы, что проявилось прогрессируюшим отеком. Автор пытался освободить вену от спаек, но они бъли такими плотныли, что мобилизация сосуда бъла невозможна. Пришлось удалить пересаженную голову, которая во время операции сохраняла условные реблексы. Собака-реципиент при этом осталась живой.

При гистологическом исследовании области операционного кожного шва бъло вылвлено заживление по типу первичного натяжения. Остальные ткани, за исключением отечного подкожного слоя, 


\section{HISTORY OF MEDIGINE}

сохранили нормальное строение. Лимфоцитарной инфильтрации обнаружено не было (выделено нами. - Авт.). Стенка [4, с. 24] полой венъ трансплантата, присоединенная $\kappa$ правой яремной вене собаки-реципиента, бъла в 4-5 раз толще за счет внешних ббиброзных наложений».

\section{О гистологических исследованиях пересаженного сердца}

"Гистологи Т.А. Григоръева, И.А. Червова ${ }^{9}$ и М.Ф. Вуйстрова проанализировали более 20 пересаженных моей командой сердеи, бункиционировавших в течение от 5 до 141 дня. Во всех случаях мышечная структура сердиа была хорошо сохранена, инбильтраиця клетками крови эндотелия и эндокарда отсутствовали.

Нервные ганглии имели тот же вид, что и в опътах по моделированию сердечной недостаточности без его <сердиа> трансплантации, которъие провела Т.А. Григорвева.

Если антитела, связанные с лимфоцитами, влияют на трансплантат, то эндокард пересаженного сердца и эндотелий коронарных сосудов должны быть инфильтрированы лимфоцитами. Но на практике этого не наблюдается (выделено нами. - Авт.).

Отторжение пересаженных внутренних органов, о чем написано в литературе, в наших многочисленных экспериментах не было зафиксировано ни разу (выделено нами. - Авт.). Изменения были такими же, как и при нарушении кровообращения того или иного органа в общей патологии человека».

То, что к 1966 г. В.П. Демихов знал о роли лимфоцитов крови в реакции отторжения, не вызывает сомнений. Но в том-то все и дело, что никакой лимфоцитарной инфильтрации в пересаженном органе его соразработчики - высококвалифицированные гистологи, не находили. И здесь мы делаем важный вывод: обвинять В.П. Демихова в том, что он не знал или не доверял иммунологии, категорически нельзя. Иммунологических реакций не видели (или не знали, в чем они заключаются) не только он (макроскопически), но и его соавторы (микроскопически).

\section{О патологоанатомических изменениях} пересаженного органа

"В некоторъх случаях регистрировали нарушение функиий почек, легких и второго сердиа, соединенных параллельно. В нескольких наблюдениях пересаженное дополнительное сердие и почку удаляли не сразу после того, как они прекраша- ли работать, а дали собаке-реципиенту жить один-два месяиа. Во время патологоанатомического исследования обнаруживали очень плотное боброзное сращение пересаженной почки, плевры и перикарда с окружающими тканями собаки-хозяина. При этом наблюдали не отторжение почки или второго сердияа, а плотные рубциь, в которые они бъли запаянъ и из которьх мобилизовать эти органы было довольно трудно.

После рассечения рубиов автор находил некробиотически дегенерированные органы плотной консистенции желтовато-серого ивета, подвергшиеся, по словам А.И. Абрикосова ${ }^{10}$, коагуляционному некрозу [2, с. 25].

Этот вид некроза характерен для общей патологии человека при инфбарктах.

Сохранение жизнедеятельности оболочек (почечной капсуль, плевры и перикарда) можно обълснить тем, что их питание осушествлялось за счет окружающей лимбьь и сосудов рубцов, которые были не очень чувствительны к нарушениям кровообращения.

В двух случаях пересадки сердияа и трех случая⿻ пересадки доли легкого, когда произошло инббииирование плевральных полостей, а антибиотики не вводились, распад трансплантатов вследствие их разложения бъи зарегистрирован через несколько дней после тромбоза магистральных сосудов в местах их шва.

В одном случае гомотрансплантат фрагмента брюшной аорты сохранил свой первоначалънъй вид через 13 лет после операции».

В этом тексте В.П. Демихов приводит мнение выдающегося советского патологоанатома, вице-президента АMH CCCP академика А.И. Абрикосова о характере изменений пересаженных органов при их длительном нахождении в нефункционирующем виде в теле хозяина: они, по мнению А.И. Абрикосова, подвергались не отторжению, а коагуляционному некрозу. В данном случае, скорее всего, А.И. Абрикосов не знал патологической анатомии реакции отторжения органов, но для В.П. Демихова его мнение было очень важным. Оно подтверждало его собственное мнение о том, что изменения трансплантата не выходят за рамки общепатологических изменений.

Интересно его наблюдение о 13-летней выживаемости гомотрансплантата брюшной аорты,

${ }^{9}$ Червова И.А. (1924-2016), советский врач-морфолог, профессор; в 1963-1990 гг. заведовала кафедрой гистологии 2-го МГМиИ им. Н.И. Пирогова (ныне кафедра морфологии МБФ РГМУ им. Н.И. Пирогова).

${ }^{10}$ Абрикосов А.И. (1875-1955), российский и советский врач-патологоанатом; Герой Социалистического Труда (1945), лауреат Сталинской премии (1942), заслуженный деятель науки (1929), академик АН СССР (1939) и АМН СССР (1944), вице-президент AMH СССР (1944-1948); в 1920-1940-х гг. был одним из лидеров отечественной патологической анатомии, возглавлял Институт нормальной и патологической морфологии АМН СССР (1944-1955); руководил вскрытием тел В.И. Ленина (1924), М.В. Фрунзе (1925), В.М. Бехтерева (1927), В.П. Ногина (1924), В.В. Куйбышева (1935) и др. 
вряд ли подвергнутого предварительному кондиционированию.

\section{О значении инфекции}

для выживания пересаженных органов

"Некоторые спечиалисты в области имлунологии устанавливают знак равенства между реакииями, происходящими при трансплантации тканей и органов внутри вида, и реакииями, вызываемыми жизнедеятельностью бактерий в организме человека. В биологическом аспекте такая идентибикаиия должна логически привести к выводу, ито для человеческого организма нет большой разнищь в том, слешивают ли они свою кровъ с кровъю другого человека или предоставляют ему әкстракт патогенных бактерий.

Алъбумин бактерий, промежуточных организмов межәу растениями и низшими животными, отличается от альбумина высших животных. Тем более чужероден альбумин патогеннъх бактерий по сравнению с альбумином совместимой группы крови и, следовательно, тканей».

Также известно, что между бактериями существует большая разнииа в их влиянии на организм человека. Некоторые бактерии (например, чумы и m.n.) вызывают слертелъные заболевания. Другие (например, вызываюшие кислотное брожение молока и т.n.) способствуют созданию питательных продуктов, которъе использует человек» [4, с. 26].

Здесь В.П. Демихов форомулирует идею о том, что антитела, наблюдаемые при пересадке органов, могут появиться в ответ на проникновение в кровь организма реципиента белка бактерий при появлении инфекции тканей в области пересадки. Таким образом, третья причина неудачи трансплантации - присоединение иноекции, влекущее за собой не только образование рубцов, но и появление антител к белкам бактерий.

\section{О значении групп крови донора} и реципиента при пересадке органов

"Согласно иммунологическим гипотезам, гибель пересаженных тканей и органов должна наступить не позднее 7, 14 и 21 дня после проведения трансплантации.

Но правда (sic! - Авт.) заключается в том, что в больиинстве экспериментов эти сроки никак не совпадают.

Самыли многочисленными являются миллионы счастливых случаев гомопластической трансплантаиии (переливания) жидких тканей (крови) с учетом группового ббактора. Бъло время, когда считалось, что клетки крови, переливаемые в новый организм, должны были быстро умирать из-за несовместимости. Но исследования с мечеными атомами показали, что введенные в новый организм эритроциты живут более 100 дней, то есть столько же, что и эритроцииты рецципиента. Повторные переливания крови от одного и того же донора также не вызывают негативных реакиий.

Кровь - самая универсальная ткань во всел теле. Влесте с клеточныли компонентами в ней обнаруживаются все растворимые составляюшие элементы всех тканей организма, включая те, которые могут бъть антигенами. Группы тканей должны совпадать с группали крови, поскольку фбакторы, их определяюшие, растворенъ в крови. Следовательно, артіоті можно предположить, ито трансплантация органов у человека с учетом совместимости групп крови и дополнительных фбакторов, учитываемых при переливании, не должна вызывать реакиии несовлестилости.

Помимо основных групп, в крови обнаружены многие сотни и тысячи дополнительных фокторов, но они не имеют практического значения для переливания крови и, следовательно, не должны иметь значения при трансплантации органов».

Идея о необходимости совпадения групп крови донора и реципиента, к которой В.П. Демихов пришел эмпирически, оказалась очень плодотворной: трансплантологи ее придерживаются до сих пор.

\section{О собаке Гришке и его дополнительном сердце, работавшем 141 день $^{11}$}

«В 1962 г. наша команда усовершенствовала процедуру трансплантации комплекса сердие-легкие в экспериментах на собаках. Это позволило продлить жизнь пересаженным органам [4, с. 27].

Согласно новой методике операиии, наибольшая выживаемость бъла у собаки Гришки (141 денъ), которой сделали трансплантацию второго, дополнительного сердиа и заленили часть левого легкого.

Собакой-реиипиентом бъла восточно-европейская овчарка, донором - взрослая, небольиих размеров дворняжка. Несмотря на принадлежность $\kappa$ разным породам, собака-реиипиент не проявила никакой реакиии несовместимости по отночению $\kappa$ трансплантату.

До последнего дня пересаженное сердиее фбункицонировало нормально, его ритм был регулярныл. В ответ на фбизическую нагрузку (бег) пересаженное сердие, как и свое собственное, учашало ритл. Через 10 минут после окончания бега пересаженное сердие возврашалось $к$ своему прежнему ритму, причем делало это намного ранъше, чем сердие реиипиента.

На 141 день после операции тоны пересаженного сердиа при аускультаиии перестали выслушиваться. Электрокардиограмла, снятая в это

${ }^{11}$ Этот раздел предисловия в целом повторяет аналогичный раздел предисловия к немецкому изданию книги (1963 г.), но изложен другими словами. 
время, показала широкие пики с низким потенициалом. После внутривенного введения гепарина сердиебиение пересаженного сердияа вновь стало прослушиваться. На электрокардиограмме, снятой В.М. Горяиновъл, пики, соответствуюшие исследуемому сердиу, вернули свой нормальнъий вид.

Однако на следующий день пересаженное сердие полностью перестало биться. Собаку пришлось усъпить. При вскрытии бъл обнаружен больиих размеров тромб в ушке правого предсердия, перекрьваюший приток крови $к$ трансплантату. Причиной появления этого тромба могли быть: нарушения кровообрашения из-за чрезмерных бизических усилий (бег) или в результате внешней травмь, поскольку ушко предсердия находилось очень близко к внешней стенке грудной клетки собаки ${ }^{12}$.

При макроскопическом исследовании миокард донорского сердиза ничем не отличался [4, с. 28] om миокарда биологического сердияа рециичента. Бъли обнаружены фбиброзные сращения с окружающими тканями реципиента в местах соединения с ними донорского сердия. В других местах плевра и перикард трансплантата не имели спаек и видимых изменений. Для проведения гистологических исследований проббессор кафбедры гистологии 2-го Московского медииинского института И.А. Червова и заведующий отделением патологической анатомии Института им. Склифосовского Н.К. Пермяков взяли фрагменты трансплантата и отправили их в Бостон (США) в ответ на запрос доктора Matlof (из клиники профессора R. Deterling) ${ }^{13}$, которъий получил новости об экспериленте от некоторых алериканских коллег, которые видели, что пес Гришка все еше жив.

Рассеченные перикард и плевра зажили первично, гистологические исследования, проведенные И.А. Червовой, показали сохранность мыиечных волокон трансплантата, и если часть нервных клеток погибла, то остальные полностью сохранилисъ.

В эпикарде наблюдались остаточные явления после его воспаления. В эндокарде изменений не заябксировано. Качественнъий проиесс, происходивший в пересаженном органе, был аналогичен таковому в сердиах со сниженной сократительной способностью, гистологическими исследованиями которых занимается вышеупомянутая кабедра.

Наблюдавшуюся в эпикарде воспалительную реакиию можно объяснить реакиией на травму во время операции и послеоперационныл воспалением инфекиионного или асептического характера.

Также наблюдались различия в фунжицих разных пересаженных органов. Так, в наших экспериментах почки, гомопластически пересаженные собакам, как правило прекращали бункционировать между 2-й и 3-й неделями; к этому времени их ткани бъли значительно изменены. Напротив, пересаженное сердие и часть легкого [4, с. 29] мало изменились даже через несколько месячев (141 денъ).

Это можно объяснить тем, что почки как бильтр организма оказываются более чувствительными $\kappa$ изменениям его внутренней средъ, а также к травмам, истощению и инбекции».

О завязывании лигатур при наложении швов

"В ходе большого количества экспериментов мъь пришли к убеждению, что успех при наложении сосудистых швов во многом обусловлен правильным их завязыванием. Когда нити затянуты слабо, узль соскалъзывают или развлзываются, что приводит к кровотечениям. И наоборот, если лигатуры затянуты ирезмерно, то повреждается интила, в результате чего образуется тромб, способный нарушить кровообращение в пересаженном органе.

Профблактическое применение гепарина $и$ бибринолизина в течение месяиа после операции при правильном контроле может предотвратить образование тромбов в областях сосудистьх швов и культей перевязанных артерий. У собак этого достичь сложно ещуе и с технической точки зрения».

О перспективах трансплантации сердца

«Если мы заглянем в будущее трансплантации органов, в частности, сердца, то сможем сделать вывод о том, что наступит время, когда в профилактических целях человеку будет пересажено второе, дополнительное (резервное) сердце, которое будет функционировать параллельно с его собственным (выделено нами; эта фраза вынесена на заднюю обложку книги (рис. 6). - Авт.)

Мъ найдем место для этого резервного сердияа в грудной клетке, но не за счет удаления доли легкого, как мъ делали это во многих наших предьдущих әкспериментах. Чтобы создать свободное пространство для второго сердиа без удаления доли легкого, мъ провели серию экспериментов, в которых пересаженное сердие было заключено в прозрачный пластиковый корпус и оставлено вне тела, в то время как его сосудъ бъли анастомозированы в грудной полости».

\section{О влиянии обструктивных заболеваний легких} на деятельность сердца

«Наблюдение через прозрачный пластиковый бутляр [4, с. 30] за бункцииял, которые выполняет пересаженное сердие, оказалось чрезвъчайно интересным и важным.

Известно, что после завершения операции грудная полость герметично зашивается, и с помошью больиого иприца из плевральных полостей удаляется лишний воздух. Аналогичное удаление воз-

${ }^{12}$ Смерть собаки, наступившая в ночь с 7 на 8-е ноября 1962 г., привела к появлению различных домыслов о ее причинах, вплоть до аутотравмы при отсутствии наблюдения за животным в праздничные дни.

${ }^{13}$ Данных о результатах этих исследований у нас нет. Возможно, не было их и у В.П. Демихова, иначе он бы о них сообщил. 


\section{HISTORY OF MEDIGIIE}

духа было проведено в случае, когда пересаженное сердие было помещено в пластиковый футляр. При этом было замечено, что в результате эвакуаиии воздуха и создания небольшого отрицательного давления вокруг сердиа, оно переставало биться. Бъло видно, что его правый желудочек расширялся, а его стенка не могла сокрашаться. После того, как отрииательное давление вокруг сердиа устранялось путем введения в футляр небольшого количества воздуха, наблюдалось восстановление сердечной деятельности.

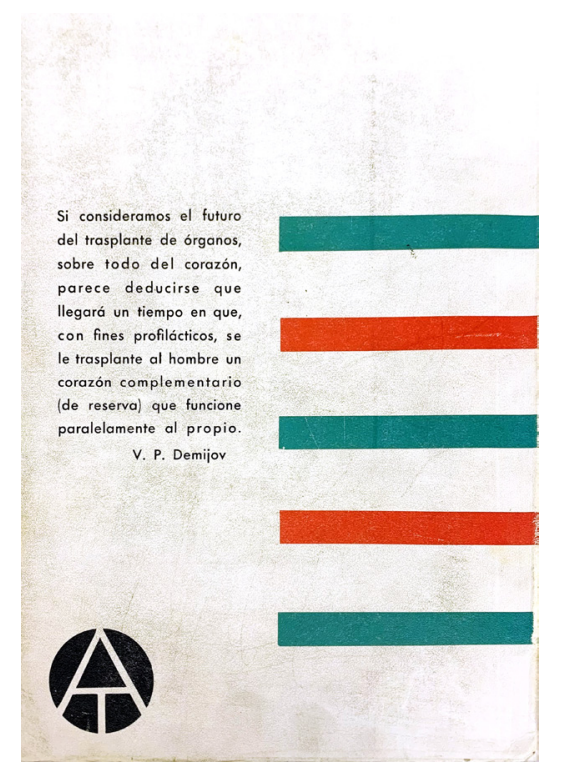

Рис. 6. Задняя обложка книги В.П. Демихова "Transplante experimental de órganos vitales" (Madrid, 1967) [Музей НМИЦ ССХ им. А.Н. Бакулева МЗ РФ]

Fig. 6. Back cover of V.P. Demikhov's book "Transplante experimental de órganos vitales" (Madrid, 1967) [Museum of A.N. Bakulev National Medical Research Center of Cardiovascular Surgery]

С фбизической точки зрения это явление вполне объяснимо: отрицательное давление в полости перикарда, окружающего сердие, это - внешняя сила, препятствуюшая увеличению объема желудочков и, как следствие, их сокращению. Стенка правого желудочка относительно тонкая, легко растягивается, а ее сопротивление в три-четыре раза менъше, чем стенки левого желудочка, что делает его неспособным преодолевать эту внешнюю силу.

Остановка сердца при создании внешнего отрицательного давления наглядно демонстрирует ошибочность веками сложившегося утверждения о том, что всасывающее действие грудной клетки является основной положительной силой, создающей приток крови к сердцу (выделено нами. - Авт.). Вопреки этому мнению, нам кажется доказанным, что отрииательное давление в грудной полости является тем механизмом, который вызывает сердечно-легочную недостаточность при хронической эмфиземе легких. Можно предположить, ито механизм этого явления состоит в том, что при хроническом бронхите затрудняется аспираиия воздуха, что приводит к возникновению отрииательного давления в грудной полости. В результате этого правый желудочек, преодолевая это внешнее давление, начинает интенсивно сокращаться [4, с. 31], что в коние кониов приводит $к$ гипертробои его стенки. При сердечно-легочной недостаточности гипертробби стенки правого желудочка является морбологическим проявлением чрезмерного отрицательного давления.

В экспериментах с двумя сердияами (без легких), проводимъх ранее, мъ нередко бъли озадаченъ ослаблением сократимости пересаженного сердияа после удаления воздуха из плевральной полости. Анализ работы сердиа, заключенного в прозрачный фбтляр, помог вылснить причину этого беномеHa».

О двухэтапной пересадке сердца и легких

"Использование прозрачного бутляра, в котором заключены сердие и легкие донора, соединенные с бедренныли сосудами реципиента, поможет сделать первъцй этап трансплантаиии сердија и легких практически безопасныл.

Если в течение одного-двух месяцев эти реанимированные органы, помещенные в оболочку и временно подключенные к организму реиипиента, не обнаружат ухудиения своей фбункииональной активности, то можно проводить второй этап операции и, только по жизненным показателям, перенести их в грудную полость.

По такому же приниипу (в два этапа) можно пересаживать и другие внутренние органы».

\section{О создании банка реанимированных (живых) органов}

"Что касается сохранения реанимированных органов для использования их в качестве трансплантатов, то лучие всего, если они будут содержаться в фбизиологических условиях, то есть при $+37,6{ }^{\circ} \mathrm{C}$ при обеспечении в них кровообращения оксигенированной кровъю реанимированным организмом, $\kappa$ которому могут быть присоединены и другие внутренние органы с соблюдением необходимой стерильности. $\kappa$ такому организму могут бътт присоединенъ новорожденнъе, мозг которъх погиб и не может быть реанимирован, а другие органъ фбункиионируют нормально. Если в этих телах (с неизлечимыми повреждениями мозга) долго сохранять [4, с. 32] жизнь реанимированных органов, то так можно выращивать все ткани и органъ, необходимые для трансплантаиии пацииентам. Таким образом, можно предположить, ито в будущем будут пересаживать органы, выращенные из реанимированных эмбрионов. Также перспективно создавать на долгое время перекрестное кровообращение между пожильм организмом, ста- 
рение которого планируется замедлить, и молодъим организмом.

Основываясь на наших собственных обширных экспериментальных данных, попытках реанимировать сердце и легкие у трупов, поступивших в клиники неотложной помощи, и на обобщении результатов исследований других ученых, наша команда разработала принципиально новый способ сохранения реанимированных органов и их культивирования для трансплантации (выделено нами. Aвm.).

На практике это можно сделать так: труп nоступает в лечебное учреждение в течение нескольких минут после смерти. В результате тяжелой травмы у него регистрируют смертельное повреждение мозга, но находят остальные органы не поврежденными, и их реанимируют вместе с сердием. С помощъю искусственного дыхания, поддержания температуры окружающей средъ на уровне $+37,5^{\circ} \mathrm{C}$, адекватной стерильности и искусственного питания это реанимированное тело, бактически лишенное головы, можно сохранять в течение длительного времени.

Не утратившие жизнедеятельность органы, взятые от других трупов, можно соединить с бедренныли сосудами этого живого тела, заключив их в специальные чехль, чтобы оживить их и сохранить в живом состоянии. $K$ такому телу также можно подключить труп новорожденного, y которого реанимировано все тело кроме мозга. Каждый подключенный орган будет выполнять свои бункици, помогая поддерживать жизнедеятельность других органов. Благодаря такой «самопомощи» органов друг другу количество тех, которые сохраняются в живом состоянии, может быть очень большим (выделено нами. - Авт.). Таким образом, реанимированное тело ребенка со смертельной травмой головного мозга будет продолжать расти, а его гормонь и обмен веществ [4, с. 33] будут способствовать омолодить всю внутреннюю среду других органов, что позволит вырастить молодье органы для трансплантаиии. От этой живой фоизологической системы органов можно вывести протезъ кровеносных сосудов большого размера и длины (несколько метров) в смежные помешения (комнаты). $K$ этим сосудам могут быть подключенъ периферические сосудъ умираюших пациентов, по которьм будет ичиркулировать аэрированная кровь, обогащенная всеми необходимыми гормонами и питательными веществами, с нормальным давлением, с учетом совместимости группъ крови.

Если в будущем этот метод будет усовершенствован до такой степени, что его применение на практике не будет опасным, пожилых людей можно будет подключить к этой системе органов или живых тел на несколько недель, чтобы изменить обмен веществ в стареющем организме с помощью молодой внутренней среды, поскольку известно, что при культивировании изолированных тканей методом «тканевых культур» после добавления экстрактов эмбриональных тканей наблюдается их омоложение (выделено В.П. Демиховым. - Авт.).

B приниипе, этот метод омоложения может быть осуществлен на индивидуальном уровне путем создания в течение длительного времени перекрестного кровообрашения между пожилым организмом и реанимированной молодой системой органов или соединяя тела с помошью сосудистьх протезов, которые в настоящее время используются для подключения, например, искусственной почки».

В первый раз об этом разработанном им способе поддержания жизни изолированных органов (а по сути дела - создания их «банка») за счет «живой фризиологической системы органов» В.П. Демихов доложил на заседании коллегии Министерства здравоохранения СССР в 1963 г. Практически одновременно эта идея была обнародована в предисловии к немецкому изданию его книги, вышедшей в том же 1963 г. То, что она появилась в предисловии к испаноязычному изданию, вышедшему в 1967 г., говорит о том, что эта идея разрабатывалась В.П. Демиховым на протяжении нескольких лет. Ее результатом станет статья в журнале «Экспериментальная хирургия», опубликованная в 1969 г. Странно, что эта идея никому не показалась несбыточной ни в 1963-м, ни в 1967-м гг. Во всяком случае нам не известны критические высказывания о ней ни в отечественной, ни в зарубежной прессе.

О приобретенной иммунологической толерантности и успешных пересадках почки человеку

"Что касается культивирования органов эмбриона, то его можно проводить в условиях, позволяюших модибициировать внутреннюю среду будущих трансплантатов, учитьвая, что следует избегать реакицй имлунизации после трансплантации.

Medawar u Gashek nредполагают, что небольшая инъекиия крови будущего реципиента в донорский эмбрион создаст необходимую толерантность и предотвратит возникновение биологической несовместимости во время будущей трансплантации. Этот метод практически применим при культивировании органов эмбриона человека [4, с. 34].

За последние 2-3 года в разных странах бъло выполнено более 1000 операций по трансплантаиии почки человеку. Согласно мировой статистике, по состоянию на 15 марта 1965 г. было выполнено 719 операиий пересадки почки, из которъх 36 между моноовулярныли близнецами и 241 - почки, взятой от трупа. Сначала казалосъ, что только трансплантация между однояйцевыли близнецами может быть успешной. В настояшее время разница в результатах пересадки почек между 


\section{HISTORY OF MEDIGINE}

донорами-близнеияами и донорами без кровного родства, а также трупных почек уменъшена. Уже есть много людей, которые несколько лет живут с почкали, взятыли не от их близнецов.

В 1963 г. из 45 пересаженных почек, взятых y трупов, заработала (исп. prendió - включить) только одна. В 1965 г. из 82 почек включились 43 ».

О недоказанности эфрфекта иммуносупрессии

"Описано много случаев трансплантации почек от обезъяны человеку, когда органъ животных фоункционировали до 100 дней. Как известно, имлунологические реакиии развиваются только в течение 1-й, 2-й и 3-й недель после введения чужеродного алъбумина (опять те же 7-й, 14-й и 21-й день. - Авт).

Во многих случаях трансплантации почек человеку используют иммуносупрессивные препаратъь - 6-меркаптопурин, имуран и т.n., тем самыл пытаясь объяснить успех трансплантаиии. Но многочисленные экспериленты на животных не подтверждают эбобективность этих препаратов, хотя, по мнению ряда исследователей, продолжительность жизни трансплантатов кожи и почек в некоторых случаях увеличивается на несколько дней.

Автор этих строк провел целую серию экспериментов на собаках с трансплантацией легких и почек и использованием меркаптопурина-6, убедившись в токсичности этого препарата и усомнившись в его эфрфективности (выделено нами. - Авт.).

Если пересаженные почки прижили у человека за счет использования иммуносупрессивных препаратов, то следует учитьвать, что применение этих же препаратов при трансплантаиии почек собакам также должно приводить к их более длительному бункиионированию. Однако, вопреки ожиданиям, этого не происходит [4, с. 35]. Максимальная продолжительность бункиии почек у собак (в условиях иммуносупрессии. - Авт.) составляет от 2- $x$ до 3-х недель и редко - от 1-го до 2-х месяцев, в то время как у человека она исчисляется годами.

Исполъзование имлуносупрессивных препаратов требует дальнейшего изучения».

\section{О создании условий для пересадки органов} на государственном уровне

"Условия лечения и ухода в послеоперачионном периоде способствуют успеху трансплантаиии почки человеку.

Необходимо также обеспечить постоянный контроль свертываемости крови, создать особые условия стерильности и ухода за паииентом, задействовать высококвалибииированный персонал. В настоящее время нет сомнений в том, что наилучшие результаты при трансплантаичи почки в клинике достигаются, когда донора и реципиента подбирают на основе совместимости их групп крови (а не их родственных отношений).
Для реализации на практике положительных результатов, достигнутых в трансплантаичи органов, на государственном уровне должны быть созданы особые условия.

Советское правительство придает большое значение этой проблеме. Министром здравоохранения назначен академик Б.В. Петровский, великий хирург и виднейший в СССР, успешно осуществивший большое количество трансплантаций почки человеку.

В.П. Демихов» [2, с. 36].

\section{Заключение}

Таким образом, анализ переведенного нами на русский язык предисловия В.П. Демихова к его книге «Пересадка жизненно-важных органов в эксперименте», вышедшей в 1967 г. на испанском языке под названием "Transplante experimental de órganos vitales", показал, что В.П. Демихов изложил в нем свои взгляды на современное ему состояние и перспективы гомопластической пересадки тканей и органов, сложившиеся у него к этому времени. Как и в предыдущих работах, в частности, в предисловии к немецкому изданию книги (Берлин, 1963) В.П. Демихов обосновал положение о том, что основным условием успешной гомопластической пересадки органов является восстановление в них кровообращения. По его мнению, успех приживления зависит, прежде всего, от идеально выполненного сосудистого шва и немедленного включения пересаженного донорского органа в кровоток организма хозяина, а также от стерильности проведенного вмешательства.

Обсудив применение фармакологической иммуносупрессии как метода преодоления биологической несовместимости гомологичных органов при их трансплантации, В.П. Демихов указал на токсичность используемых для этой цели препаратов, испытанных им в условиях эксперимента, а также на свои опыты, указывающие на возможность преодоления несовместимости другими методами (подбор донора и реципиента по группам крови, смешивание крови донора и реципиента путем парабиоза и др.).

В данной работе В.П. Демихов вновь описал и обосновал разработанную им схему пересадки дополнительного сердца в качестве резервного для поддержания функции ослабленного биологического сердца больного в два этапа: 1-й этап подсадка на бедренные сосуды, 2-й этап - трансплантация в грудную клетку, но технику выполнения 2-го этапа не описал. «Мы найдем место 
для этого резервного сердца в грудной клетке, сообщил он, - но не за счет удаления доли легкого, как мы делали это во многих наших предыдущих экспериментах. Чтобы создать свободное пространство для второго сердца без удаления доли легкого, мы провели серию экспериментов, в которых пересаженное сердце было заключено в прозрачный пластиковый корпус и оставлено вне тела, в то время как его сосуды были анастомозированы в грудной полости». Однако из этого текста не ясно, как В.П. Демихов собирался «создать свободное пространство для второго сердца без удаления доли легкого»? Из этого можно сделать вывод о том, что сам он такой двухэтапной трансплантации не проводил. Во всяком случае, нам такие опыты не известны.

Как и в предисловии к немецкому изданию книги, В.П. Демихов вновь изложил разработанную им в 1963 г. модель «живой физиологической системы» для создания банка реанимированных органов с целью поддержания их жизнедеятельности до пересадки, а также для выращивания органов у новорожденных диэнцефралов и для омоложения стариков.

Особенность данного текста, впервые введенного нами в научный оборот, заключается в следующем. С одной стороны, многочисленные фракты указывают на то, что в 1-й половине 1960-х гг. В.П. Демихов тщательно следил за всеми литературными новинками в области трансплантологии и трансплантационного иммунитета, включая иностранные источники, вышедшие в 1965 г., включив ссылки на них в предоставленный им для перевода на испанский язык текст предисловия. С другой стороны, сравнив предисловия к берлинскому (1963) и мадридскому (1967) изданиям, мы легко увидим отсутствие в них каких-либо принципиальных отличий.

Это может свидетельствовать о том, что в эти годы, несмотря на изменение парадигмы в области трансплантации гомоорганов, взгляды В.П. Демихова на эту проблему остались прежними и к этому времени стали уже архаичными. Его фрундаментальное биолого-физиологическое образование и многолетний личный опыт разработки биологических методов преодоления несовместимости тканей при гомопластических пересадках органов (рис. 7) прочно связывали его по рукам и ногам, не давая ни шагнуть, ни заглянуть вперед.

Если рассмотреть данную ситуацию с позиций работ И. Лакатоса (1922-1974) о методологии научно-исследовательских программ, то «жестким ядром» многолетней научно-исследовательской работы В.П. Демихова будет его убежденность в том, что биологическая несовместимость тканей и органов преодолима. В конечном итоге оказалось, что в этом В.П. Демихов был абсолютно прав.

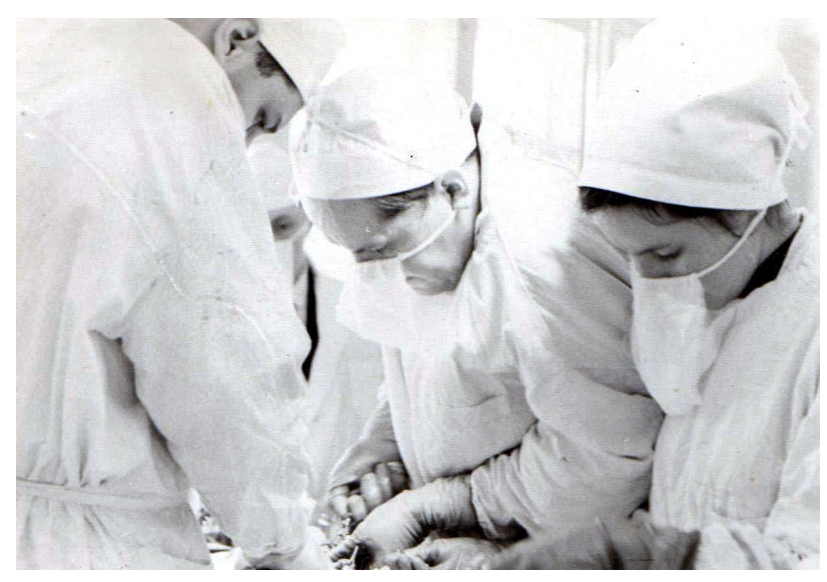

Рис. 7. В.П. Демихов (в центре) в операционной [Музей НМИЦ ССХ им. А.Н. Бакулева МЗ РФ]

Fig. 7. V.P. Demikhov (center) in the operating room [Museum of A.N. Bakulev National Medical Research Center of Cardiovascular Surgery]

Это - важнейший вывод, который позволяет нам считать исследования, проводимые им на протяженим 20 с лишним лет, не тупиковой ветвью трансплантологии, а одним из начальных, во многом эмпирических ее этапов.

В таком случае «защитным поясом» программы В.П. Демихова стала его теория о ведущей роли восстановления кровообращения и длительной фрункции трансплантата в его приживлении, а положительной эвристикой - результаты экспериментов, не укладывающиеся в прокрустово ложе современных ему иммунологических теорий, которые он с легкостью опровергал (например, сроки отторжения, которые постулировали его современники - 7-й, 14-й и 21-й день; или лимфоцитарную инфильтрацию, которую в его опытах не находили профессиональные морфологи высокого уровня и др.).

Вместе с тем, по нашему мнению, во второй половине 1960-х гг. научно-исследовательская программа В.П. Демихова уже прошла свою прогрессивную стадию и постепенно стала регрессировать. Это подтверждается тем, что эмпирическое содержание выстраиваемого В.П. Демиховым «защитного пояса» (например, фракт выживания в 1962 г. второго сердца у пса Гришки в течение 141 дня) уже не могло рассматриваться в каче- 
стве положительной эвристики и в свою очередь было опровергнуто 593 днями жизни второго пациента C. Barnard'a, Philip'a Blaiberg'a, оперированного в январе 1968 г.

С этой точки зрения «испанский след» в жизни В.П. Демихова можно считать одним из элементов отрицательной эвристики его программы, когда основные усилия ученого были направлены не на дальнейшее развитие ее «жесткого ядра», а на латание дыр в его «защитном поясе» с помощью поиска все новых и новых гипотез, подбираемых ad hoc ${ }^{14}$.

K сожалению, близилось время, когда связь «защитного пояса» с «жестким ядром» научно-исследовательской программы В.П. Демихова ослабнет настолько, что ему придется признать ее несостоятельность. И. Лакатос назвал этот момент «пунктом насыщения», когда на смену существующей программе приходит альтернативная [12].

\section{Литература}

1. Демихов В.П. Пересадка жизненно-важных органов в эксперименте. Москва: Медгиз; 1960.

2. Demikhov VP. Experimental Transplantation of Vital Organs. New-York: Consultants Bureau Enterprises; 1962.

3. Demichow W. Die experimentelle Transplantation lebenswichtiger Organe. Berlin: VEB Verlag Volk und Gesundheit; 1963

4. Demijov VP. Transplante experimental de órganos vitales. Madrid: Editorial Atlante; 1967.

5. Писанко Н. Самые распространенные языки мира. В электронной версии: "Коммерсантъ» от 21.03.2019. URL: https://www.kommersant.ru/ doc/3917583 [Дата обращения 24 декабря 2020 г.]

6. Amano T, González-Varo JP, Suther- land WJ. Languages are still a major barrier to global science. PLOS Biology. 2016;14(12):e2000933 https://doi. org/10.1371/journal.pbio.2000933

7. Вернер А., Глянцев С.П. Монография В.П. Демихова «Пересадка жизненно-важных органов в эксперименте» (1960) в зарубежной научной печати (к 50-летию первой пересадки сердца человеку). Трансплантология. 2017;9(4):360-370. https://doi. org/10.23873/2074-0506-2017-9-4-360370

8. Глянцев С.П., Вернер А. Феномен Демихова. В Институте им. Н.В. Склифосовского (1960-1986 гг.) Demichow W. Die experimentelle Transplantation lebenswichtiger Organe. Berlin: VEB Verlag Volk und Gesundheit, 1963. трансплантология. 2020;12(1):61-75. https://doi.org/10.23873.2074-05062020-12-1-61-75

9. Литвинов А.В., Литвинова И.А. Нобелевская плеяда медииинской науки: Энииклопедия лауреатов. Смоленск; 2008.

10. Войно-Ясенецкий В.В. Тканевая несовместимость и пути ее преодоления. Москва: Медицина; 1965.

11. Schwind JV. Homotransplantation of extremities by parabiosis. Ann NY Acad Scienc. 1962;99(3):933942. PMID: 13992448 https://doi. org/10.1111/j.1749-6632.1962.tb45372.x 12. Лакатос И. Фальсификаиия и методология научно-исследовательских програмл. Москва; 1995. URL: https:// gtmarket.ru/laboratory/basis / 4369 [Дата обращения 24 декабря 2020 г.]

\section{References}

1. Demikhov VP. Peresadka zhiznenno vazhnykh organov $v$ eksperimente. Moscow: Medgiz Publ.; 1960. (In Russ.). 2. Demikhov VP. Experimental Transplantation of Vital Organs. New-York: Consultants Bureau Enterprises; 1962.

3. Demichow W. Die experimentelle transplantation lebenswichtiger organe. Berlin: VEB Verlag Volk und Gesundheit; 1963.

4. Demijov VP. Transplante experimental de órganos vitales. Madrid: Editorial Atlante; 1967.

5. Pisanko N. Samye rasprostranennye yazyki mira. Kommersant, March
21, 2019. Available at: https://www. kommersant.ru/doc/3917583 [Accessed December 24, 2020]. (In Russ.).

6. Amano T, González-Varo JP, Sutherland WJ. Languages are still a major barrier to global science. PLOS Biology. 2016;14(12):e2000933 https://doi. org/10.1371/journal.pbio.2000933

7. Werner A, Glyantsev SP. V.P. Demikhov's monograph "Transplantation of vital organs In experiment" (1960) in foreign scientifi c press (to the $50^{\text {th }}$ anniversary of the fi rst heart transplantation in human). Transplantologiya. The Russian Journal of Transplantation.
2017;9(4):360-370. (In Russ.). https:// doi.org/10.23873/2074-0506-2017-9-4360-370

8. Glyantsev SP, Werner A. Phenomenon of Demikhov. In the Sklifosovsky Institute (1960-1986). Demichow W. Die experimentelle Transplantation lebenswichtiger Organe. Berlin: VEB Verlag Volk und Gesundheit, 1963. Transplantologiya. The Russian Journal of Transplantation. 2020;12(1):61-75. (In Russ.). https://doi.org/10.23873/2074-05062020-12-1-61-75

9. Litvinov AV, Litvinova IA. Nobelevskaya pleyada meditsinskoy nauki:

\footnotetext{
14 Латинское выражение, означающее «специально для этого», «по особому случаю».
} 


\section{ИнтоРИі МЕдИциНЫ}

\section{HISTORY OF MEDIGIIE}

Entsiklopediya laureatov. Smolensk; 2008. (In Russ.).

10. Voyno-Yasenetskiy VV. Tkanevaya nesovmestimost' $i$ puti ee preodoleniya. Moscow: Meditsina Publ.; 1965. (In Russ.). 11. Schwind JV. Homotransplanta- tion of extremities by parabiosis. Ann NY Acad Scienc. 1962;99(3):933942. PMID: 13992448 https://doi. org/10.1111/j.1749-6632.1962.tb45372.x

12. Lakatos I. Fal'sifikatsiya i metodologiya nauchno-issledovatel'skikh pro- gramm. Moscow; 1995. Available at: https://gtmarket.ru/laboratory/ basis/4369 [Accessed December 24, 2020]. (In Russ.).

\section{Информация об авторах}

профр., д-р мед. наук, руководитель отдела истории сердечно-сосудистой хирургии

Сергей Павлович

Сергей Г
Глянцев

\section{Юлия Георгиевна Шатунова}

Артур Вернер

Sergey P. Glyantsev

Yuliya G. Shatunova

Artur Werner ФГБУ «НМИЦ ССХ им. А.Н. Бакулева» МЗ РФ, заведующий сектором истории медицины и фактографии отдела истории медицины ФГБНУ «ННИИ ОЗ им. H.А. Семашко», https://orcid.org/0000-0003-2754-836X $50 \%$ - идея, поиск источников, их анализ, написание статьи

студентка ФГБОУ ВО Первый МГМУ им. И.М. Сеченова МЗ РФ, https://orcid. org/0000-0002-0936-9803

$30 \%$ - литературный перевод предисловия с испанского, редактирование

доктор медицины, ординатор клиники кардиоторакальной хирургии ХЕЛИОСклиники Крефельда

$20 \%$ - поиск источников, их перевод и анализ, редактирование

\section{Information about the authors}

Prof., Dr. Sci. (Med.), Head of the Department of the History of Cardiovascular Surgery at A.N. Bakulev National Medical Research Center for Cardiovascular Surgery; Head of the History of Medicine and Factual Account Unit within the History of Medicine Department at N.A. Semashko National Research Institute of Public Health, https://orcid.org/0000-0003-2754-836X

$50 \%$, idea, search for literature sources, their analysis, writing the article

student, I.M. Sechenov First Moscow State Medical University (Sechenov University), https://orcid.org/0000-0002-0936-9803

$30 \%$, literary translation of the Preface from Spanish, editing

Dr. Med., Resident Doctor at Cardiothoracic Surgery Clinic, HELIOS Hospital Krefeld $20 \%$, search for literature sources, their translation and analysis, redacting
Статья поступила в редакцию 16.12.2020;

одобрена после рецензирования 18.12.2020;

принята к публикации 21.12.2020
The article was received on December 16, 2020; approved after reviewing December 18, 2020; accepted for publication December 21, 2020 